\title{
Plot size and replications number for triticale experiments
}

\author{
Marcos Toebe ${ }^{* *}$ (i) Alberto Cargnelutti Filho ${ }^{2}$ (i) Anderson Chuquel Mello ${ }^{3}$ (i) \\ Rafael Rodrigues de Souza $^{3}$ (i) Franciéle dos Santos Soares ${ }^{4}$ (i) Lucas Santos da Silva $^{4}$ (i) \\ Alexandre Segatto 5 (i)
}

'Departamento de Ciências Agronômicas e Ambientais, Universidade Federal de Santa Maria (UFSM), Campus Frederico Westphalen, 98400-000, Frederico Westphalen, RS, Brasil. E-mail: m.toebe@gmail.com. "Corresponding author.

${ }^{2}$ Departamento de Fitotecnia, Universidade Federal de Santa Maria (UFSM), Santa Maria, RS, Brasil.

${ }^{3}$ Programa de Pós-graduação em Agronomia, Agricultura e Ambiente, Universidade Federal de Santa Maria (UFSM), Campus Frederico Westphalen, Frederico Westphalen, RS, Brasil.

${ }^{4}$ Curso de Agronomia, Universidade Federal do Pampa (UNIPAMPA), Campus Itaqui, Itaqui, RS, Brasil.

${ }^{5}$ Engenheiro Agrônomo, NUFARM BRASIL ${ }^{\circledR}$, Santo Ângelo, RS, Brasil.

\begin{abstract}
The hybridization between wheat and rye crops resulted in the triticale crop, which presents rusticity, versatility in animal and human food and possibility of use as a cover plant. The objective of this research was to determine the optimal plot size and the replications number to evaluate the fresh weight of triticale in two evaluation moments. An experiment was carried out with the triticale cultivar IPRI11. The experimental area was divided into 48 uniformity trials, each containing 36 basic experimental units of $0.51 \mathrm{~m}^{2}$. The fresh weight was evaluated in 24 uniformity trials at 99 days after sowing (DAS) and in 24 uniformity trials at 127 DAS. The optimal plot size was determined by the method of the maximum curvature of the coefficient of variation and the replications number was determined in scenarios of treatments number and differences between means to be detected as significant by Tukey test. To determine the fresh weight of triticale, the optimal plot size is $3.12 \mathrm{~m}^{2}$, with coefficient of variation of $13.69 \%$. Six replications are sufficient to identify as significant, differences between treatment means of $25 \%$ for experiments with up to seven treatments and of $30 \%$ for experiments with up to 28 treatments, regardless of the experimental design. Key words: $\times$ Triticosecale Wittmack, uniformity trials, experiment planning.
\end{abstract}

Tamanho de parcela e número de repetições para experimentos de triticale

RESUMO: O cruzamento das culturas de trigo e centeio resultou na obtenção da cultura do triticale, que apresenta rusticidade, versatilidade na alimentação animal e humana e possibilidade de uso como planta de cobertura. O objetivo deste trabalho foi determinar o tamanho ótimo de parcela e o número de repetições para avaliar a massa verde de triticale em dois momentos de avaliação. Foi conduzido um experimento com a cultivar de triticale IPR111, sendo a área experimental dividida em 48 ensaios de uniformidade, cada ensaio contendo 36 unidades experimentais básicas de 0,51 $\mathrm{m}^{2}$. A massa verde foi avaliada em 24 ensaios aos 99 dias após a semeadura (DAS) e em 24 ensaios aos 127 DAS. O tamanho ótimo de parcela foi determinado pelo método da máxima curvatura do coeficiente de variação e o número de repetições foi determinado em combinações de número de tratamentos e de diferenças entre médias a serem detectadas como significativas pelo teste de Tukey. Para determinar a massa verde de triticale, o tamanho ótimo de parcela é de 3,12 $\mathrm{m}^{2}$ com coeficiente de variação de $13,69 \%$. Seis repetições são suficientes para identificar como significativas, diferenças entre médias de tratamentos de $25 \%$ para experimentos com até sete tratamentos e de $30 \%$ para experimentos com até 28 tratamentos, independentemente do delineamento experimental.

Palavras-chave: $\times$ Triticosecale Wittmack, ensaios de uniformidade, planejamento experimental.

The hybridization between wheat (Triticum sp.) and rye (Secale sp.), aiming to combine the growth ability under unfavorable conditions of rye with the food use versatility of wheat, resulted in the origin of the triticale ( $\times$ Triticosecale Wittmack - ZHU, 2018). Due to high protein concentration, the triticale has potential for use in animal feed, as fodder, silage and grain and in human diets as a complementary cereal in several foods and beverages (SUCU \& ÇIFCI, 2016; ZHU, 2018). Furthermore, according to ALBRECHT et al. (2018), triticale is one of the most used species of cover crops in the western region of Parana State.

In experiments with triticale, several combinations between plot sizes and replications 
number were used, for example, plots of $6 \mathrm{~m}^{2}$ to 16.8 $\mathrm{m}^{2}$, evaluation areas in plots from $0.25 \mathrm{~m}^{2}$ to $1.2 \mathrm{~m}^{2}$ and three to four repetitions (SUCU \& ÇIFCI, 2016; ALBRECHT et al., 2018). The lack of experimental protocols indicating the optimal plot size and number of replications, may result in experiments with low reliability or requiring excessive use of human, financial and time resources. Therefore, the objective of this research was to determine the optimal plot size and the replications number to evaluate the fresh weight of triticale in two evaluation moments.

An experiment was carried out with triticale cultivar IPR111 in the experimental area situated in latitude $29^{\circ} 09^{\prime} 25^{\prime}$ ' $\mathrm{S}$, longitude $56^{\circ} 33^{\prime}$ $16^{\prime \prime} \mathrm{W}$ and altitude of $74 \mathrm{~m}$, with Cfa climate and soil classified as "Haplic Plinthosol" (SANTOS et al., 2013). The seeding procedure was performed on June 3, 2016, with spacing of $0.17 \mathrm{~m}$ between rows and final plant population in the harvest of 1294117 plants ha ${ }^{-1}$. Basic fertilization was carried out with 20 $\mathrm{kg} \mathrm{ha}^{-1}$ of $\mathrm{N}, 80 \mathrm{~kg} \mathrm{ha}^{-1}$ of $\mathrm{P}_{2} \mathrm{O}_{5}$ and $80 \mathrm{~kg} \mathrm{ha}^{-1}$ of $\mathrm{K}_{2} \mathrm{O}$ and two topdressing fertilizations were performed with $40 \mathrm{~kg} \mathrm{ha}^{-1}$ of $\mathrm{N}$ in each one.

The useful area of the experiment was divided into 48 uniformity trials. Each uniformity trial of size $6 \mathrm{~m} \times 3.06 \mathrm{~m}\left(18.36 \mathrm{~m}^{2}\right)$, was divided into 36 basic experimental units (BEU) of $1.0 \mathrm{~m} \times 0.51 \mathrm{~m}$ $\left(0.51 \mathrm{~m}^{2}\right.$ - one meter $\times$ three rows $)$, forming a matrix of six rows and six columns. The fresh weight was evaluated in each BEU of 24 uniformity trials at 99 days after sowing (DAS) and in each BEU of 24 uniformity trials at 127 DAS, respectively, in anthesis completed and soft dough stages, as described by ZADOKS et al. (1974). Plants were cut near the soil surface and the fresh weight determined in grams per $0.51 \mathrm{~m}^{2}$.

For each uniformity trial with fresh weight of $36 \mathrm{BEU}$, were determined the first-order spatial autocorrelation coefficient (obtained in the rows direction), variance, mean, variation coefficient of the trial, optimal plot size and the variation coefficient in the optimal plot size, using the equations described by PARANAÍBA et al. (2009) and applied by CARGNELUTTI FILHO et al. (2014). Next, the number of replications was determined in scenarios formed by combinations of $i$ treatments $(i=3,4$, ..., 100) and $d$ minimum differences among means of treatments to be detected as significant at 5\% probability by Tukey test, expressed as a percentage of experiment mean $(\mathrm{d}=10 \%, 15 \%, \ldots, 40 \%)$, by iterative process until convergence, as detailed and applied by CARGNELUTTI FILHO et al. (2014). Statistical analyzes were performed with Microsoft Office
Excel $^{\circledR}$ and software R (R DEVELOPMENT CORE TEAM, 2020).

There were no significant differences between the two evaluation moments (99 and 127 DAS) for the variables first-order spatial autocorrelation coefficient and mean (Table 1). For the variation coefficient of the trial, the optimal plot size and the variation coefficient in the optimal plot size, higher values were observed in the first evaluation moments, indicating greater variability between BEU in anthesis completed stage in relation to the soft dough stage. Among the 48 uniformity trials, the fresh weight ranged from $684.73 \mathrm{~g}$ to $1178.21 \mathrm{~g}$ per BEU (13426 kg ha-1 to $23102 \mathrm{~kg} \mathrm{ha}^{-1}$ ), with a overall mean of $904.93 \mathrm{~g}$ per BEU (17744 kg $\mathrm{ha}^{-1}$ ). In the evaluation of forage yields at the dough stage in triticale lines, SUCU \& ÇIFCI (2016) obtained forage production of up to $44.28 \mathrm{t} \mathrm{ha}^{-1}$ of fresh weight. Several genetic and management factors may explain the lower values of fresh weight in the present study, but the main one is related to the condition of lowland soils (Haplic Plinthosol), susceptible to waterlogging in which the experiment was conducted. Conversely, using the same cultivar as the present study, ALBRECHT et al. (2018) obtained lower fresh weight values in two-years experiments ( $5655 \mathrm{~kg} \mathrm{ha}^{-1}$ and $\left.7145 \mathrm{~kg} \mathrm{ha}^{-1}\right)$, perhaps by the use of larger spacing.

The variation coefficient of the trial ranged from $13.56 \%$ to $34.21 \%$ (Table 1 ), with a mean value of $21.30 \%$ and the optimal plot size ranged from 1.61 $\mathrm{m}^{2}$ to $3.12 \mathrm{~m}^{2}$, with a mean value of $2.15 \mathrm{~m}^{2}$ (Table 1). The variation coefficient in the optimal plot size ranged from $7.04 \%$ to $13.69 \%$ among the 48 uniformity trials, with a mean value of $9.44 \%$, considered low by PIMENTEL-GOMES (2009). In order to ensure greater reliability in the experimental design, the highest optimal plot size among the 48 uniformity trials $\left(3.12 \mathrm{~m}^{2}\right)$ was recommended for use in the evaluation of the fresh weight of triticale in anthesis completed and soft dough stages. The correspondent variation coefficient in the optimal plot size (13.69\%), was used to calculate the number of replications for experiments in the completely randomized design and in the complete randomized block design.

The replications number varied between 2.7 and 69.5 (Figures 1A, B), with similar behavior for completely randomized and complete randomized block designs. The replications number increases with increasing number of treatments and of desired precision, i.e., with the lowest level of $d(d$ $=10 \%$ ), as expected and described in the literature (CARGNELUTTI FILHO et al., 2014). The number 
Table 1 - First order spatial autocorrelation coefficient $(\rho)$, variance $\left(\mathrm{s}^{2}\right)$, mean $\left(\mathrm{m}\right.$, in grams per basic experimental unit of $\left.0.51 \mathrm{~m}^{2}\right)$, trial coefficient of variation $\left(\mathrm{CV}\right.$, in \%), optimal plot size $\left(\mathrm{Xo}\right.$, in BEU of $0.51 \mathrm{~m}^{2}$ and in $\left.\mathrm{m}^{2}\right)$ and the coefficient of variation in the optimal plot size $\left(\mathrm{CV}_{\mathrm{Xo}}\right.$, in $\%)$ for the fresh weight of triticale cultivar IPR111 in two evaluation moments (99 and 127 days after sowing).

\begin{tabular}{|c|c|c|c|c|c|c|c|c|}
\hline DAS & Trial $^{(1)}$ & $\rho$ & $s^{2}$ & $\mathrm{~m}(\mathrm{~g})$ & CV (\%) & Xo (BEU) & $\mathrm{Xo}\left(\mathrm{m}^{2}\right)$ & $\mathrm{CV}_{\mathrm{Xo}}(\%)$ \\
\hline 99 & 2 & -0.02 & 62451.56 & 859.91 & 29.06 & 5.53 & 2.82 & 12.36 \\
\hline 99 & 4 & 0.19 & 40932.75 & 864.54 & 23.40 & 4.73 & 2.41 & 10.57 \\
\hline 99 & 5 & 0.26 & 39842.81 & 893.89 & 22.33 & 4.53 & 2.31 & 10.13 \\
\hline 99 & 8 & 0.22 & 22868.68 & 891.59 & 16.96 & 3.80 & 1.94 & 8.50 \\
\hline 99 & 9 & 0.63 & 33974.87 & 781.39 & 23.59 & 4.06 & 2.07 & 9.07 \\
\hline 99 & 10 & 0.49 & 83221.06 & 925.56 & 31.17 & 5.29 & 2.70 & 11.83 \\
\hline 99 & 11 & 0.48 & 46361.95 & 897.78 & 23.98 & 4.45 & 2.27 & 9.96 \\
\hline 99 & 12 & 0.14 & 90843.89 & 880.91 & 34.21 & 6.12 & 3.12 & 13.69 \\
\hline 99 & 16 & 0.57 & 46891.67 & 689.58 & 31.40 & 5.09 & 2.60 & 11.39 \\
\hline 99 & 17 & 0.08 & 37603.26 & 787.13 & 24.64 & 4.94 & 2.52 & 11.05 \\
\hline 99 & 18 & 0.27 & 28483.60 & 684.73 & 24.65 & 4.83 & 2.46 & 10.79 \\
\hline 99 & 19 & 0.40 & 50603.57 & 716.96 & 31.38 & 5.48 & 2.80 & 12.25 \\
\hline 99 & 20 & 0.22 & 40985.31 & 1066.05 & 18.99 & 4.09 & 2.09 & 9.16 \\
\hline 99 & 21 & 0.50 & 31180.30 & 915.73 & 19.28 & 3.82 & 1.95 & 8.53 \\
\hline 99 & 22 & -0.13 & 28463.63 & 1178.21 & 14.32 & 3.43 & 1.75 & 7.67 \\
\hline 99 & 23 & 0.72 & 82776.31 & 928.20 & 31.00 & 4.52 & 2.30 & 10.10 \\
\hline 99 & 24 & 0.32 & 34497.41 & 994.01 & 18.69 & 3.98 & 2.03 & 8.89 \\
\hline Mean - 99DAS & - & $0.31 \mathrm{a}^{(2)}$ & 49131.44a & $879.09 \mathrm{a}$ & $24.94 \mathrm{a}$ & $4.70 \mathrm{a}$ & $2.39 \mathrm{a}$ & $10.50 \mathrm{a}$ \\
\hline 127 & 8 & 0.46 & 53637.44 & 1157.45 & 20.01 & 3.98 & 2.03 & 8.90 \\
\hline 127 & 9 & 0.50 & 28626.97 & 1107.80 & 15.27 & 3.28 & 1.67 & 7.33 \\
\hline 127 & 10 & 0.36 & 21798.58 & 943.72 & 15.64 & 3.49 & 1.78 & 7.81 \\
\hline 127 & 11 & 0.44 & 20988.26 & 962.19 & 15.06 & 3.31 & 1.69 & 7.41 \\
\hline 127 & 12 & -0.07 & 27793.21 & 870.82 & 19.14 & 4.18 & 2.13 & 9.34 \\
\hline 127 & 13 & 0.19 & 16580.49 & 877.05 & 14.68 & 3.46 & 1.77 & 7.75 \\
\hline 127 & 14 & 0.56 & 34671.78 & 887.39 & 20.98 & 3.92 & 2.00 & 8.76 \\
\hline 127 & 15 & 0.23 & 23939.28 & 756.72 & 20.45 & 4.29 & 2.19 & 9.60 \\
\hline 127 & 16 & 0.29 & 33785.18 & 931.22 & 19.74 & 4.15 & 2.11 & 9.27 \\
\hline 127 & 17 & 0.45 & 24691.31 & 985.84 & 15.94 & 3.43 & 1.75 & 7.68 \\
\hline 127 & 18 & 0.23 & 23233.13 & 1028.53 & 14.82 & 3.46 & 1.77 & 7.74 \\
\hline 127 & 19 & 0.52 & 42573.39 & 1008.68 & 20.46 & 3.94 & 2.01 & 8.80 \\
\hline 127 & 20 & 0.16 & 33289.96 & 789.34 & 23.11 & 4.70 & 2.40 & 10.51 \\
\hline 127 & 21 & 0.35 & 23316.17 & 836.07 & 18.26 & 3.89 & 1.98 & 8.69 \\
\hline 127 & 22 & 0.13 & 24218.87 & 865.83 & 17.97 & 3.99 & 2.03 & 8.92 \\
\hline 127 & 23 & 0.33 & 14526.17 & 768.15 & 15.69 & 3.53 & 1.80 & 7.89 \\
\hline 127 & 24 & 0.32 & 18453.17 & 910.71 & 14.92 & 3.42 & 1.74 & 7.65 \\
\hline Mean - 127DAS & - & $0.33 \mathrm{a}$ & $27740.14 b$ & $930.77 \mathrm{a}$ & $17.67 \mathrm{~b}$ & $3.75 b$ & $1.91 \mathrm{~b}$ & $8.38 b$ \\
\hline Overall Mean & - & 0.32 & 38435.79 & 904.93 & 21.30 & 4.22 & 2.15 & 9.44 \\
\hline
\end{tabular}

${ }^{(1)}$ Each uniformity trial of $6 \mathrm{~m} \times 3.06 \mathrm{~m}\left(18.36 \mathrm{~m}^{2}\right)$, was divided into 36 basic experimental units (BEU) of $1.0 \mathrm{~m} \times 0.51 \mathrm{~m}\left(0.51 \mathrm{~m}^{2}-\right.$ one meter $\times$ three rows), forming a matrix of six rows and six columns. ${ }^{(2)}$ For each statistic $\left(\rho, s^{2}, m, C V, X o\right.$ and $\left.C V_{\mathrm{Xo}}\right)$, the means not followed by the same letter in the column (comparison of means between the evaluation days) differ at 5\% significance by Student's t-test (bilateral) for independent samples. 


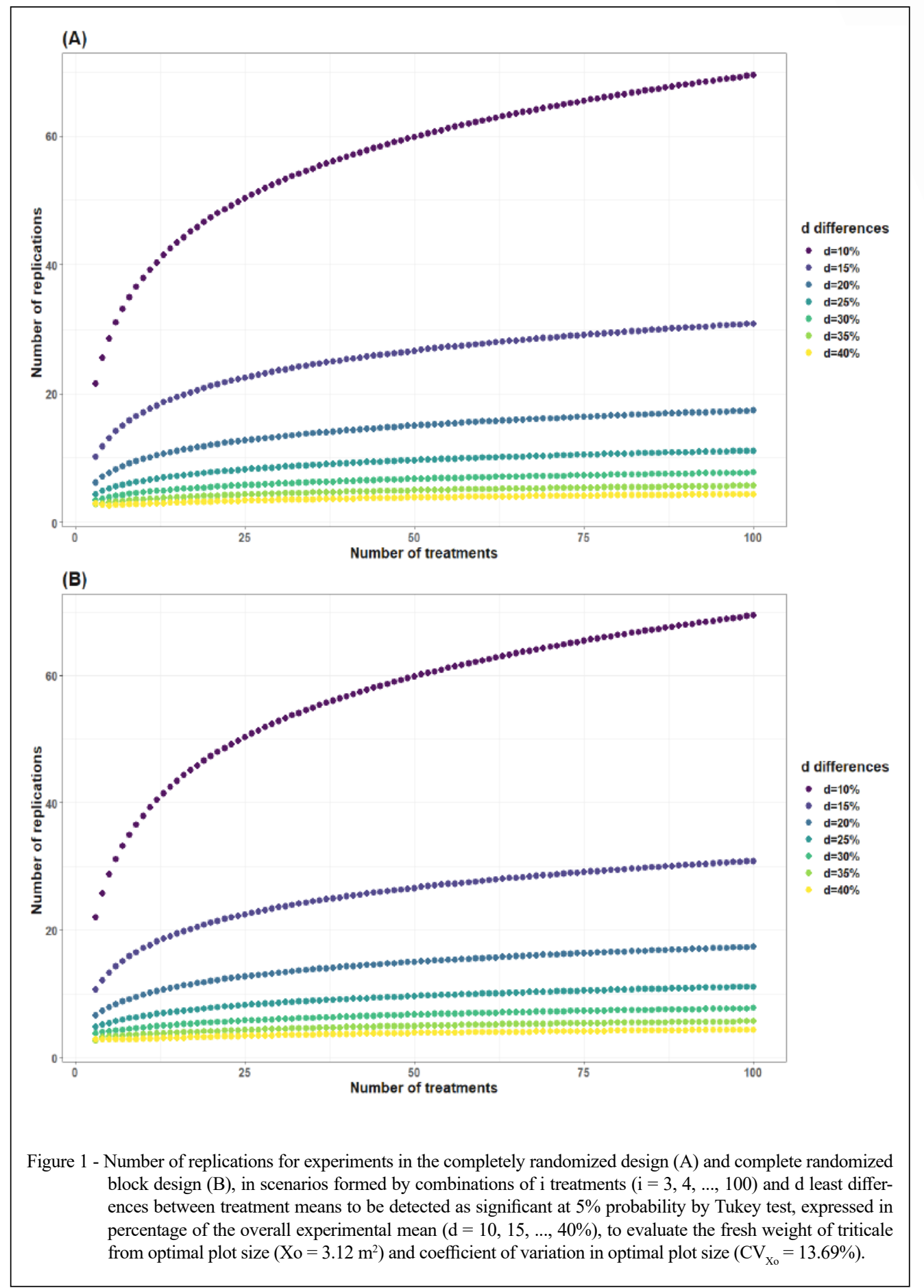

of replications to the triticale fresh weight evaluation was presented in 1372 conditions (combination of 98 possible numbers of treatments $\times$ seven levels of $d$ minimum differences among means $x$ two experimental designs), allowing the reader/researcher to identify the number of replications recommend for each case. For example, if the researcher uses six replications, he can identify as significant, differences between treatment means of $25 \%$ for experiments with up to seven treatments, of $30 \%$ for experiments with 
up to 28 treatments and of $35 \%$ for experiments with up to 100 treatments, regardless of the experimental design used. In black oats, CARGNELUTTI FILHO et al. (2014) recommended plots of $4.14 \mathrm{~m}^{2}$ and four replications to identify as significant differences between treatment means of $26.7 \%$.

In an experiment of triticale conducted by SUCU \& ÇIFCI (2016) in Bursa, Turkey, plots of $6 \mathrm{~m}^{2}$ and three replications were used in a complete randomized block design. However, for the evaluation of forage yields at the dough stage, forage samples were harvested in an area of 1.2 $\mathrm{m}^{2}$. For experiments with triticale and six other species of cover crops, ALBRECHT et al. (2018) used a complete randomized block design with four replications and plot of $16.8 \mathrm{~m}^{2}$. However, for the evaluation of fresh and dry matter, they used a sample are of $0.25 \mathrm{~m}^{2}$. In conclusion, to determine the fresh weight of triticale, the optimal plot size is $3.12 \mathrm{~m}^{2}$, with coefficient of variation of $13.69 \%$. Six replications are sufficient to identify as significant, differences between treatment means of $25 \%$ for experiments with up to seven treatments and of $30 \%$ for experiments with up to 28 treatments, regardless of the experimental design used.

\section{ACKNOWLEDGEMENTS}

To the Fundação de Amparo à Pesquisa do Estado do Rio Grande do Sul (FAPERGS - Process number 16/2551-0000257-6 ARD/PPP), to the Conselho Nacional de Desenvolvimento Científico e Tecnológico (CNPq Process numbers 401045/2016-1 and 304652/2017-2), to the Coordenação de Aperfeiçoamento de Pessoal de Nível Superior (CAPES - Brasil Finance code 001), to the Programa de Educação Tutorial (PET) of Ministério da Educação and to the Fundação Universidade Federal do Pampa (UNIPAMPA) by scholarships and financial support.

\section{DECLARATION OF CONFLICT OF INTERESTS}

The authors declare no conflict of interest. The founding sponsors had no role in the design of the study; in the collection, analyses, or interpretation of data; in the writing of the manuscript, and in the decision to publish the results.

\section{AUTHORS' CONTRIBUTIONS}

MT designed and supervised the experiment. ACM, RRS, FSS, LSS and AS performed the experiments and data collection. ACF performed the statistical analyses. MT prepared the draft of the manuscript. All authors critically revised the manuscript and approved of the final version.

\section{REFERENCES}

ALBRECHT, L. P. et al. Performance of fall and winter crops in a no tillage system in West Paraná State. Acta Scientiarum, v.40, e34999, p.1-9, 2018. Available from: <https://dx.doi.org/10.4025/ actasciagron.v40i1.34999>. Accessed: Mar. 20, 2020. doi: 10.4025/ actasciagron.v40i1.34999.

CARGNELUTTI FILHO, A. et al. Plot size and number of repetitions in black oat. Ciência Rural, v.44, n.10, p.17321739, 2014. Available from: <https://dx.doi.org/10.1590/01038478cr20131466>. Accessed: Mar. 20, 2020. doi: 10.1590/0103$8478 \mathrm{cr} 20131466$.

PARANAÍBA, P. F. et al. Optimum experimental plot size: Proposition of estimation methods. Revista Brasileira de Biometria, v.27, n.2, p.255-268, 2009. Available from: <http:// jaguar.fcav.unesp.br/RME/fasciculos/v27/v27_n2/Patricia. pdf $>$. Accessed: Mar. 20, 2020.

PIMENTEL-GOMES, F. Curso de estatística experimental. $15^{\mathrm{a} e d .}$ Piracicaba: FEALQ, 2009. 451p.

R DEVELOPMENT CORE TEAM. R: a language and environment for statistical computing. Vienna: $\mathrm{R}$ Foundation for Statistical Computing. 2020. Available from: <http:// www.R-project.org>. Accessed: Mar. 20, 2020.

SANTOS, H.G. et al. Sistema brasileiro de classificação de solos. Brasília: EMBRAPA, 2013. 353p.

SUCU, E.; ÇIFCI, E. A. Effects of lines and inoculants on nutritive value and production costs of triticale silages. Revista Brasileira de Zootecnia, v.45, p.355-364, 2016. Available from: <https:// dx.doi.org/10.1590/S1806-92902016000700001>. Accessed: Mar. 20, 2020. doi: 10.1590/S1806-92902016000700001.

ZADOKS, J. C. et al. A decimal code for the growth stages of cereals. Weed Research, v.14, p.415-421, 1974. Available from: <https:// onlinelibrary.wiley.com/doi/abs/10.1111/j.1365-3180.1974. tb01084.x>. Accessed: Mar. 20, 2020. doi: 10.1111/j.13653180.1974.tb01084.x.

ZHU, F. Triticale: Nutritional composition and food uses. Food Chemistry, v.241, p. 468-479, 2018. Available from: <https://doi. org/10.1016/j.foodchem.2017.09.009>. Accessed: Mar. 20, 2020. doi: 10.1016/j.foodchem.2017.09.009. 